\title{
Falling asleep
}

Eric Forsbergh, DDS

Neurology ${ }^{\circledR}$ 2019;92:967. doi:10.1212/WNL.0000000000007509

A sudden twitch as you begin to drift.

It's quick. Sometimes with a frisson of fear:

about to plummet from a cliff.

It too has a name, known to few, but nameless it remains to most of us.

Will you conclude it was intrusions of a dream?

An aura saturating the room, the perimeter of bedposts

marking off the architecture in the room?

Or, a replay of that moment when your older brother halfway slipped gripping your hand down in that dim well, while your dad, oblivious,

forever rounds the barn?

Perhaps, a synapse snapping off after thirty years, the memory of a lover, each of you a shadow spent,

now on your own side of another bed?

Or, by its truest name,

hypnagogic myoclonus passing through, broaching on a terror as you age:

encroaching loss of self-control.

Or just, as realization hardens in the dark, your body practicing for death,

objecting one last time

to letting go?
Correspondence

Dr. Forsbergh

forsber@verizon.net

MORE ONLINE

ค Audio

Listen to Dr. Forsbergh

read this poem.

NPub.org/8gq7do 


\title{
Neurology
}

\author{
Falling asleep \\ Eric Forsbergh \\ Neurology 2019;92;967 \\ DOI 10.1212/WNL.0000000000007509
}

This information is current as of May 13, 2019

$\begin{array}{ll}\begin{array}{l}\text { Updated Information \& } \\ \text { Services }\end{array} & \begin{array}{l}\text { including high resolution figures, can be found at: } \\ \text { http://n.neurology.org/content/92/20/967.full }\end{array} \\ \text { Permissions \& Licensing } & \begin{array}{l}\text { Information about reproducing this article in parts (figures,tables) or in } \\ \text { its entirety can be found online at: } \\ \text { http://www.neurology.org/about/about_the_journal\#permissions }\end{array} \\ & \begin{array}{l}\text { Information about ordering reprints can be found online: } \\ \text { http://n.neurology.org/subscribers/advertise }\end{array}\end{array}$

Neurology ${ }^{\circledR}$ is the official journal of the American Academy of Neurology. Published continuously since 1951, it is now a weekly with 48 issues per year. Copyright (O 2019 American Academy of Neurology. All rights reserved. Print ISSN: 0028-3878. Online ISSN: 1526-632X.

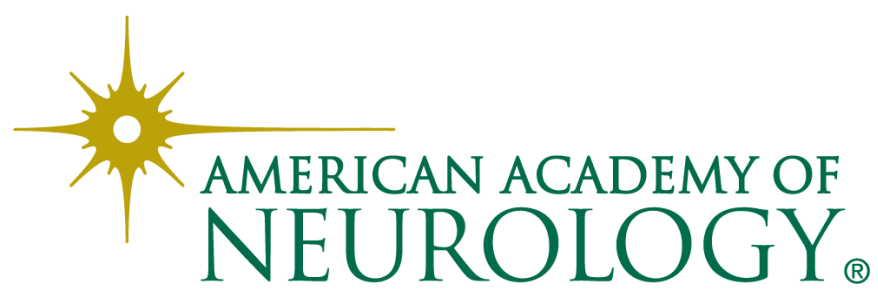

